\title{
A Surface Modifier for the Production of Selectively Activated Amino Surface Groups
}

\author{
Kirill Puchnin ${ }^{1,2, * \mathbb{C}}$, Vitaliy Grudtsov ${ }^{1}$, Maria Andrianova ${ }^{1}$, Stanislav Bezzubov ${ }^{3}$ and \\ Alexander Kuznetsov ${ }^{1}$ (D) \\ 1 Scientific-Manufacturing Complex Technological Center, 1-7 Shokin Square, Zelenograd, Moscow 124498, \\ Russia; vitaliycatgrudcov@gmail.com (V.G.); smariika1987@gmail.com (M.A.); kae@tcen.ru (A.K.) \\ 2 Department of Chemistry, M.V. Lomonosov Moscow State University, 1-3 Leninskiye Gory, GSP-1, \\ Moscow 119991, Russia \\ 3 Russian Academy of Sciences, N.S. Kurnakov Institute of General and Inorganic Chemistry, 31 Leninskii pr., \\ Moscow 119991, Russia; stas.bezzubov@gmail.com \\ * Correspondence: puchninkv@yandex.ru
}

Received: 12 September 2019; Accepted: 30 October 2019; Published: 2 November 2019

check for updates

\begin{abstract}
The formation of self-assembled monolayers with the possibility of selective activation is an important goal of surface chemistry. In this work, a new surface modifier which creates amino surfaces based on aminopropylsilatrane (APS) with a protected amino group was obtained. The utilization of protected APS allows producing a self-assembled monolayer (SAM) and obtaining reactive surface amino groups at distinct times. Furthermore, a precise selective deprotection with a further modification of the activated amino groups could be performed without affecting the protected groups. To demonstrate the practical applicability of this modifier, a trinitrotoluene-sensitive sensor based on an ion-sensitive field-effect transistor (ISFET) was obtained.
\end{abstract}

Keywords: surface modification; self-assembled monolayer; cross-linker; terminal amine; protecting group; biosensor

\section{Introduction}

Organic linkers used for the covalent immobilization of biological and organic molecules, as well as nanoparticles have a wide range of roles in the modern natural sciences. The most common class of such surface modifiers is organosilanes [1]. The presence of alkoxy or halogen groups in these molecules allows them to easily interact with surface hydroxy groups, in particular, in silicon structures. This allows for the immobilization of various molecules in microelectronic devices [2].

Aminosilanes play a distinct role in organosilanes. The most commonly used aminosilane is (3-aminopropyl) triethoxysilane (APTES) [3]. It is used in various applications, for example, as the coupling agent for the modification of silica surfaces to increase adhesion in fiberglass-epoxy composites, as a polymer film on glass, for the production of temperature- and photo-responsive films, to immobilize proteins and cells, and to attach nanoparticles [4]. Despite such a wide distribution, APTES has drawbacks, e.g., it is very sensitive to moisture, which leads to its agglomeration and polymerization on a substrate during deposition and can cause multilayer deposition and irregular surface morphology [5]. $\gamma$-Aminopropylsilatrane (APS) is used to obtain a surface amino layer as an alternative to APTES [6]. Unlike APTES, APS is less reactive and extremely resistant to hydrolysis and polymerization at neutral $\mathrm{pH}$ [7]. However, neither APTES nor APS can withstand long-term storage at room conditions because they both contain a terminal amino group.

The amino surfaces resulting from treatment with APTES or APS are subject to degradation over time and can react with various reagents. Protective groups are used to solve these problems [8]. 
The presence of protective groups also allows for the selective deprotection of certain areas of the surface, which itself allows for further modifications. One method of deprotection is the electrochemical method [9]. The benzoquinone-hydroquinone system is often used to generate acid during electrochemical deprotection [10]. The acid released at the anode creates a local decrease of $\mathrm{pH}$, thereby removing the protective groups near it. Cathode products react with $\mathrm{H}^{+}$, preventing the removal of protective groups outside the anode region [11,12]. The compound 1,2-Diphenylhydrazine is also used to electrochemically decrease the $\mathrm{pH}$ to remove tert-butoxycarbonyl (Boc) protecting groups [13].

In this work, a new surface modifier was obtained based on an N-protected APS. tert-Butoxycarbonyl (Boc) was chosen as the protective group because of its capacity for deprotection in an acidic medium, as well as its availability and the ease of formation of the protection. The main reason for using this modifier is to separate in time the formation of thin films and the removal of the protective groups to obtain surface amino groups. This will allow the introduction of additional stages in the processing of the sample prior to the activation of the amino groups, as well as the selective removal of protective groups for subsequent functionalization. Such a modifier can be useful for the selective immobilization and fabrication of biosensors.

\section{Materials and Methods}

\subsection{Materials}

All chemicals received from commercial sources were used without further purification. Streptavidin-peroxidase conjugate and recombinant Escherichia coli nitroreductase K12 were obtained from Sigma Aldrich (St. Louis, MO, USA). Streptavidin-glucose oxidase conjugate was obtained from Fitzgerald Industries International (Acton, MA, USA). Solvents were purified and dried according to standard procedures. $\gamma$ APS was synthesized according to published procedures [14].

For the synthesis of N-tert-butoxycarbonylaminopropylsilatrane (BocAPS), APS (0.4 g, $1.7 \mathrm{mmol})$, di-tert-butyl dicarbonate $\left(\mathrm{Boc}_{2} \mathrm{O}, 1.2 \mathrm{~mL}, 5.1 \mathrm{mmol}\right)$, and triethylamine $\left(\mathrm{Et}_{3} \mathrm{~N}, 1.4 \mathrm{~mL}, 10.2 \mathrm{mmol}\right)$ were mixed in anhydrous dimethylformamide (DMF, $50 \mathrm{~mL}$ ) and stirred at room temperature for 2 days. After this time, the solvent was evaporated. The residue was recrystallized from toluene, resulting in a colorless crystallin powder $(0.56 \mathrm{~g}, 99 \%$ yield $)$.

The p-type silicon boron-doped wafer (Ameks, Russia) was cleaned with Caro solution followed by chemical etching in an $\mathrm{HF}-\mathrm{HCl}$ solution. The cleaned surface was treated by plasma oxidation followed by annealing at $300{ }^{\circ} \mathrm{C}$ for $30 \mathrm{~min}$. The wafer was then cut into $4 \mathrm{~mm} \times 4 \mathrm{~mm}$ or $7 \mathrm{~mm} \times 20 \mathrm{~mm}$ slides.

n-Channel silicon-on-insulator (SOI) ion-sensitive field-effect transistors (ISFETs) were manufactured at the SMC Technological Center, Russia, according to the $1.2 \mu \mathrm{m}$ complementary metal-oxide-semiconductor (CMOS) process. The sensitive surface of the ISFETs was a $\mathrm{SiO}_{2}$ layer.

\subsection{NMR and Crystallography Measurements}

All NMR spectra were acquired at $25^{\circ} \mathrm{C}$ on a Bruker AVANCE 400 spectrometer (Karlsruhe, Germany). Chemical shifts are reported in ppm, referenced to solvent signals (see Supplementary material Figures $\mathrm{S} 1$ and S2). BocAPS NMR ${ }^{1} \mathrm{H}\left(\mathrm{CDCl}_{3}, 400 \mathrm{MHz}\right), \delta$, ppm: 4.91 b.s. $(1 \mathrm{H}, \mathrm{NH}), 3.76 \mathrm{t}(6 \mathrm{H}$, $\left.J=5.8 \mathrm{~Hz}, \mathrm{CH}_{2} \mathrm{O}\right), 3.09 \mathrm{~m}\left(2 \mathrm{H}, \underline{\mathrm{C}}_{2} \mathrm{NH}\right), 2.80 \mathrm{t}\left(6 \mathrm{H}, J=5.8 \mathrm{~Hz}, \mathrm{CH}_{2} \mathrm{~N}\right), 1.58 \mathrm{~m}\left(2 \mathrm{H}, \mathrm{CH}_{2} \mathrm{C}_{2} \mathrm{CH}_{2}\right), 1.42 \mathrm{~s}$ $\left(9 \mathrm{H}, \mathrm{C}\left(\mathrm{CH}_{3}\right)_{3}\right), 0.42 \mathrm{~m}\left(2 \mathrm{H}, \mathrm{CH}_{2} \mathrm{Si}\right) . \mathrm{NMR}^{13} \mathrm{C}\left(\mathrm{CDCl}_{3}, 100 \mathrm{MHz}\right), \delta, \mathrm{ppm}: 156.01(\mathrm{C}=\mathrm{O}), 78.29\left(\mathrm{CH}_{2} \mathrm{NH}\right)$, $\left.57.64\left(\mathrm{CH}_{2} \mathrm{O}\right), 50.99\left(\mathrm{CH}_{2} \mathrm{~N}\right), 43.46\left(\mathrm{CH}_{2} \underline{\mathrm{CH}}_{2} \mathrm{CH}_{2}\right), 28.45\left(\mathrm{C}_{(\mathrm{CH}}\right)_{3}\right), 24.88\left(\underline{\mathrm{C}}\left(\mathrm{CH}_{3}\right)_{3}\right), 13.17\left(\mathrm{CH}_{2} \mathrm{Si}\right)$.

For the interaction with glutaraldehyde, $6.6 \mathrm{mg}(0.02 \mathrm{mmol})$ BocAPS or $4.6 \mathrm{mg}(0.02 \mathrm{mmol})$ APS and $640 \mu \mathrm{L} \mathrm{D} \mathrm{D}_{2} \mathrm{O}$ were mixed in an NMR tube. Then, $12 \mu \mathrm{L}(25 \%, 0.03 \mathrm{mmol})$ glutaraldehyde was added. After $30 \mathrm{~min}$, the ${ }^{1} \mathrm{H}$ NMR spectrum was recorded (Figure S3). No studies were carried out with (3-aminopropyl) triethoxysilane (APTES), because it was rapidly hydrolyzed under our experimental conditions. 
The X-ray single-crystal data were collected at $290 \mathrm{~K}$ on a Enraf-Nonius CAD4 diffractometer using graphite monochromatized $\mathrm{Cu}-\mathrm{K} \alpha$ radiation $(\lambda=1.54178 \AA)$ in the $\omega$-scan mode. Absorption corrections based on measurements of equivalent reflections were applied [15]. The structure was solved by direct methods and refined by the full-matrix least-squares method on $\mathrm{F}^{2}$ with anisotropic thermal parameters for all nonhydrogen atoms in the Olex2 software package [16]. Hydrogen atoms were placed in calculated positions and refined using a riding model. The silatrane fragment was found to be rotationally disordered over two positions with occupancies of $0.62 / 0.38$. The second component of the disorder was rotated about the $\mathrm{Si}-\mathrm{N}$ bond by 38.4(3) with respect to the first component. Crystallographic data are presented in the Supporting Information (Table S1).

\subsection{Monolayer Preparation and Modification}

The slides were treated with UV-generated ozone in a BioForce UV/Ozone Pro-Cleaner ozone generator (Ghent, NY, USA) for $10 \mathrm{~min}$ to refresh the surface oxides. The slides were then submerged into a toluene solution of BocAPS (6.6 mg BocAPS in $15 \mathrm{~mL}$ toluene) and incubated for $3 \mathrm{~h}$ at $70{ }^{\circ} \mathrm{C}$, prior to rinsing with dichloromethane and drying. The obtained films were then characterized by contact angle. The ISFET monolayers were prepared in a similar manner.

Water-wetting contact angle measurements were conducted at room temperature $\left(20^{\circ} \mathrm{C}\right)$ using an OCA 15EC DataPhysics Instrument (Filderstadt, Germany). Deionized water (electrical resistance = 18.2 $\mathrm{M} \Omega \mathrm{cm}$ ) was dropped onto each surface, and the contact angles were assessed using SCA 20 software (Version 4.3.19).

X-ray photoelectron spectroscopy (XPS) was performed with a Specs PHOIBOS 150 MCD (Berlin, Germany) instrument using monochromatic $\mathrm{Mg} \mathrm{K} \alpha$ X-rays (1253.6 eV). The source power was $225 \mathrm{~W}$. The pass energy was set at 40 and $10 \mathrm{eV}$ for the survey regions and the narrow regions, respectively. Spectral calibration was determined by setting the main $\mathrm{C}_{1 \mathrm{~s}}$ component at $286 \mathrm{eV}$.

Before removing the protective groups from the self-assembled monolayer (SAM) on the ISFET, epoxy structures of the well type were created on their surface according to the described procedure [17].

The general method of chemical removal of protective groups was as follows: The slides modified with BocAPS were placed in a solution of trifluoroacetic acid and dichloromethane (1:1) for $30 \mathrm{~min}$ at room temperature. Next, they were rinsed with dichloromethane and dried.

The general method of electrochemical removal of protective groups was as follows: Two silicon slides were connected to an Agilent B1500A semiconductor device parameter analyzer and immersed in an acetonitrile solution of benzoquinone $(25 \mathrm{mM})$, hydroquinone $(25 \mathrm{mM})$, and tetrabutylammonium hexafluorophosphate $(25 \mathrm{mM})$. One of the slides was maintained at $0 \mathrm{~V}$, making it the cathode, the other was maintained at a variable voltage (with the limit of $30 \mathrm{~V}$ ) to establish a current of $200 \mu \mathrm{A}$ between the slides, making this slide the anode. This setup was maintained for $40 \mathrm{~min}$, then the slides were washed with acetonitrile and dried. In the case of the ISFET, a platinum reference electrode was used as the anode $\left(\mathrm{V}_{\mathrm{g}}=2.5 \mathrm{~V}\right)$, the sensitive surface of the ISFET was used as the cathode, and the drain and the source were connected to the source ground $\left(\mathrm{V}_{\mathrm{d}}=\mathrm{V}_{\mathrm{s}}=0 \mathrm{~V}\right)$.

The slides were incubated in a 5\% glutaric dialdehyde solution in water for $1 \mathrm{~h}$ at room temperature. The slides were then thoroughly washed with phosphate-buffered saline (PBS, pH 7.4) and incubated overnight with $0.01 \mathrm{mg} / \mathrm{mL}$ of enzyme (glucose oxidase or nitroreductase) solution in PBS at $1{ }^{\circ} \mathrm{C}$, then washed 5 times with PBS.

\subsection{Measurement of Enzyme Activity}

Glucose oxidase activity was measured using a microplate spectrofluorimeter (Infinite ${ }^{\circledR}$ M200, Tecan, Switzerland) and Bio-One 655001 microplates (Greiner Bio-One, Kremsmünster, Austria). The reaction was carried out in $0.1 \mathrm{M}$ citrate-phosphate buffer, $\mathrm{pH}$ 5.5. The reaction mixture contained $3,3^{\prime}, 5,5^{\prime}$-tetramethylbenzidine (TMB, $\left.0.3 \mathrm{mM}\right)$, glucose (1.2 mM), and horseradish peroxidase (HRP, $\left.6 \times 10^{-8} \mathrm{M}\right)$. The volume of the reaction mixture in the wells was adjusted to $100 \mu \mathrm{L}$. Enzyme-modified 
slides were placed in the wells. Kinetic measurements were performed at room temperature for $4 \mathrm{~h}$, and the increase in absorbance at $650 \mathrm{~nm}$ was recorded.

The measurement of nitroreductase activity using an ISFET was performed according to a method previously described [18], using a semiconductor device parameter analyzer (Agilent B1500A, Santa Clara, CA, USA) and a probe station (CascadeMicrotech PM5, Beaverton, OR, USA) operated by the Agilent VEE Pro software (Version A.04.20).

\section{Results and Discussion}

\subsection{Synthesis and Characterization of BocAPS}

The synthesis of BocAPS was carried out in two stages (Figure 1). In the first stage, APS was obtained according to the described procedure by condensing APTES with triethanolamine (TEA) in the presence of sodium as a catalyst [14]. In the second stage, the amine protective group was introduced by reacting it with $\mathrm{Boc}_{2} \mathrm{O}$. BocAPS, obtained with a yield of $99 \%$, turned out to be a fairly stable compound. In contrast to most common surface modifiers with a terminal amino group (APS and APTES), BocAPS does not degrade when stored without special conditions (at room temperature without an inert gas) for several years (see Supplementary data Figure S4).

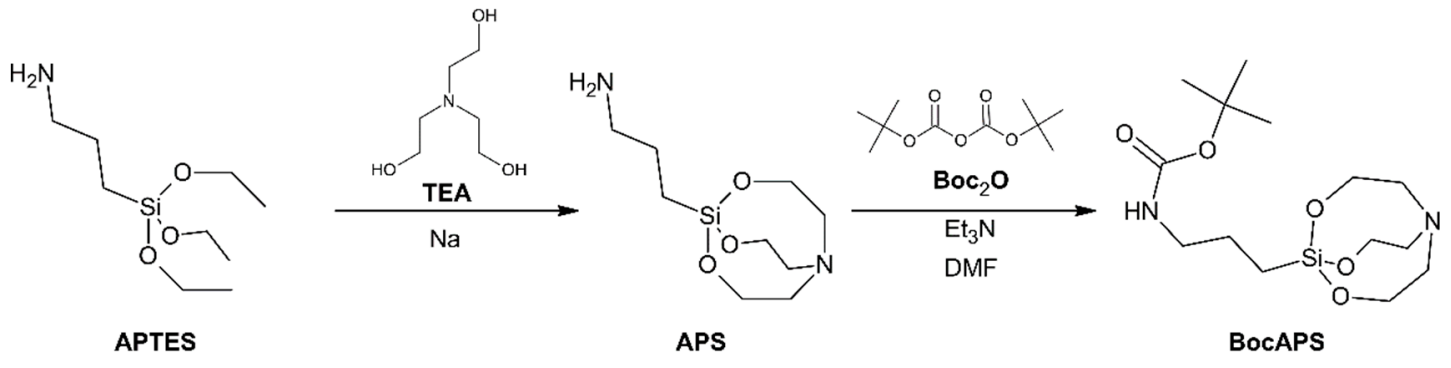

Figure 1. Synthesis of N-tert-butoxycarbonylaminopropylsilatrane (BocAPS).

The structure of the obtained BocAPS was confirmed by ${ }^{1} \mathrm{H}$ and ${ }^{13} \mathrm{C}$ NMR spectra, as well as $\mathrm{X}$-ray structural analysis. X-ray-quality single crystals of BocAPS were grown by slow cooling a toluene solution of the substance (Deposition Number CCDC-1952855, Figure 2). The $\mathrm{Si} \leftarrow \mathrm{N}$ donating bond length is 2.154(3) $\AA$, which is similar to those observed in other $\gamma$-organopropylsilatranes and in methylsilatrane [19]. The molecule has a moderate intramolecular $\mathrm{N}-\mathrm{H}-\mathrm{O}$ hydrogen bond between the amide fragment and the oxygen atom of the silatrane fragment $(\mathrm{d}(\mathrm{N}-\mathrm{O})=2.950(3) \AA)$.

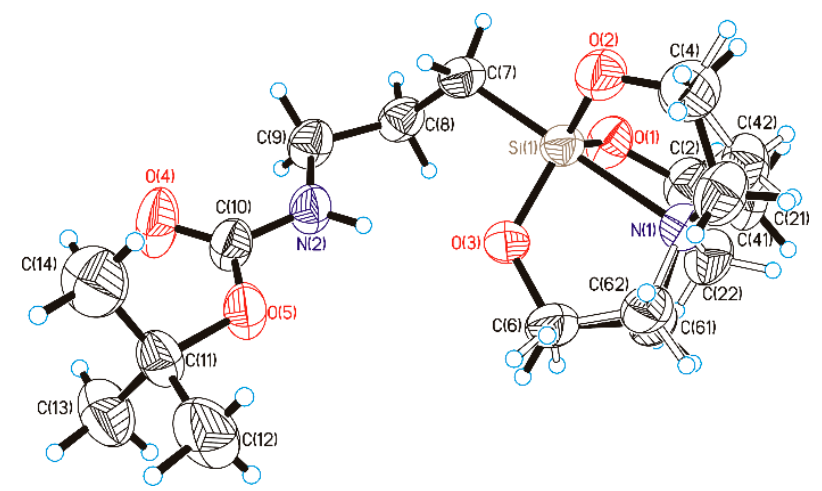

Figure 2. Molecular structure of BocAPS. Displacement ellipsoids are shown at the $50 \%$ probability level.

In order to check the protective properties of the Boc-group, NMR studies of the interaction of BocAPS with glutaraldehyde were carried out. Glutaraldehyde was chosen as a commonly used reagent for the further modification of surfaces with terminal amino groups [20]. When glutaraldehyde 
was added to the BocAPS solution in $\mathrm{D}_{2} \mathrm{O}$, there was no noticeable change in the ${ }^{1} \mathrm{H}$ NMR spectra for 30-60 min: the signals of both BocAPS and glutaraldehyde were present in the spectrum without changing intensity over time (see Supplementary data Figure S3). In turn, unprotected APS reacted with glutaraldehyde under the same conditions within a few seconds. Thus, BocAPS can be used to achieve selective interaction with amino modifiers: Removing Boc groups activates amino groups, while the presence of Boc groups prevents their interaction with amino modifiers.

\subsection{Formation and Modification of a BocAPS SAM}

The formation of a BocAPS SAM on silicon slides bearing a surface silicon dioxide layer was investigated. The slide surface was initially treated with UV-generated ozone to remove any organic admixtures and regenerate free hydroxyl groups on the surface to provide maximum density of immobilized BocAPS molecules. BocAPS was attached to the surface by prolonged heating of the slides in a BocAPS-toluene solution. During the immobilization of BocAPS, the surface was covered with terminal tert-butyl groups (Figure 3d), which led to a change in its hydrophilicity. Thus, the completeness of the immobilization process could be estimated by measuring the wetting angle. The wetting angle of the bare slide was $5 \pm 3^{\circ}$ (after clearing with UV-ozone, Figure $3 a$ ) and after the modification of the slide by BocAPS, it increased to $75 \pm 3^{\circ}$ (Figure $3 b$ ). This confirmed the successful immobilization of BocAPS on the surface of $\mathrm{SiO}_{2}$.

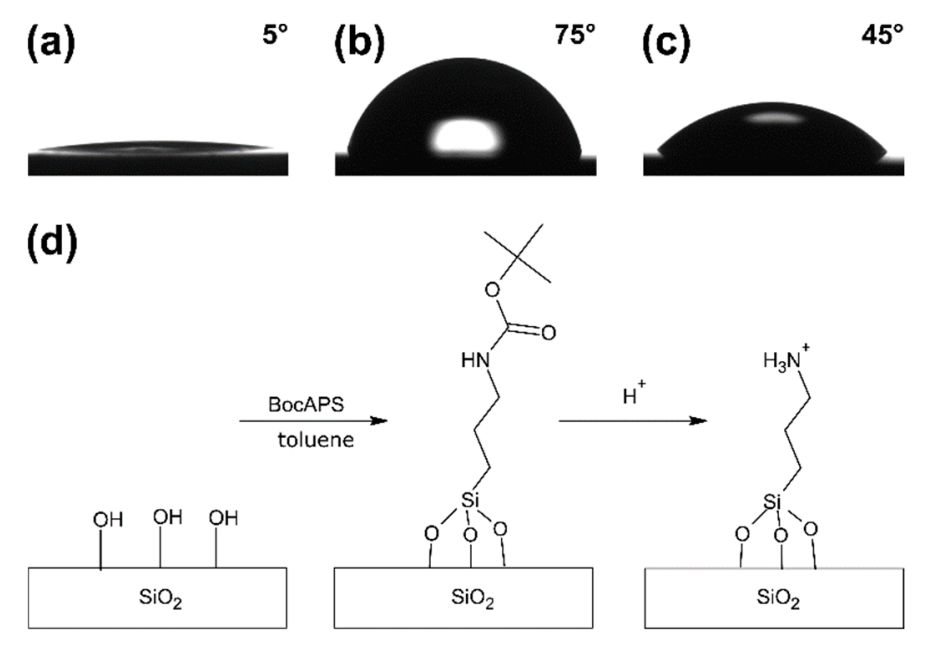

Figure 3. Water-drop profiles on the bare $\mathrm{SiO}_{2}$ surface (after clearing with UV-ozone) (a), BocAPS-modified $\mathrm{SiO}_{2}$ surface (b), and BocAPS-modified $\mathrm{SiO}_{2}$ surface after removing the Boc groups (c). Scheme of self-assembled monolayer (SAM) formation and removal of the protective group (d).

It is known that the protective Boc group is removed in an acidic medium. Thus, for the chemical removal of Boc groups, the most frequently used method in the literature involves a solution of trifluoroacetic acid in methylene chloride [21]. It was shown that the optimal solution for deprotection was a 1:1 mixture of trifluoroacetic acid and methylene chloride applied for $30 \mathrm{~min}$. In this case, the contact angle of the surface decreased to $45^{\circ}$ (Figure 3c), which is close to the wetting contact angle value for the $\mathrm{NH}_{3}{ }^{+}$-group indicated in the literature [2].

For the electrochemical removal of protective groups, an anode-cathode system consisting of two silicon slides connected to an Agilent B1500A and immersed in an acetonitrile solution of benzoquinone, hydroquinone, and tetrabutylammonium hexafluorophosphate, was used. It is worth noting that, in contrast to works where the protective groups are removed by electrochemical generation of an acid in the anode area [22], in this case, the acidity of the medium was not enough to remove the Boc groups. The removal of the protective groups occurred at the cathode, similar to the cathodic removal of the benzyloxycarbonyl protecting group in the production of amine and $\mathrm{CO}_{2}$ [23]. Variations in voltage, current, and time in the experiments showed that for $7 \mathrm{~mm} \times 20 \mathrm{~mm}$ silicon slides, the treatment for 
$40 \mathrm{~min}$ with a voltage corresponding to a current of $200 \mu \mathrm{A}$ between the electrodes (with a voltage limit of $30 \mathrm{~V}$ ) was sufficient for the removal of the protective group (this result was reproducible; see Supplementary data Figure S5).

XPS studies were also used to analyze the attachment of BocAPS and the consequent surface modifications. The full survey spectrum (see Supplementary data Figure S6) showed characteristic $\mathrm{N}_{1 \mathrm{~s}}, \mathrm{C}_{1 \mathrm{~s}}$, and $\mathrm{O}_{1 \mathrm{~s}}$ signals from immobilized BocAPS. A decrease in the $\mathrm{N}_{1 \mathrm{~s}}$ signal was observed in the survey spectra of the slides which underwent both chemical and electrochemical deprotection. This was due to the hydrolysis of residues of triethanolamine, which were not completely removed at the stage of immobilization. The removal of the Boc group was confirmed by the dramatic changes in the high-resolution spectra of $\mathrm{C}_{1 \mathrm{~s}}$ (Figure 4): the component at $290 \mathrm{eV}$ decreased upon removal of the Boc group, which corresponds to the $\mathrm{O}-\mathrm{C}=\mathrm{O}$ fragment.
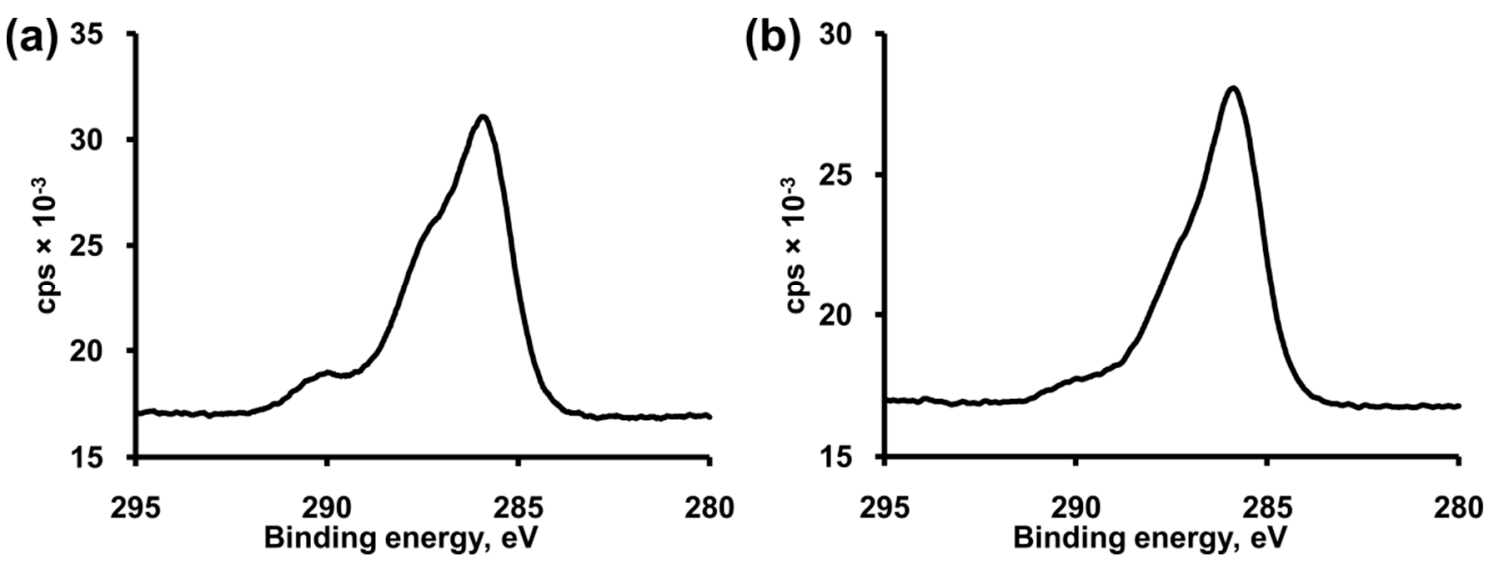

Figure 4. XPS spectra recorded over the $\mathrm{C}_{1 \mathrm{~s}}$ region of the BocAPS-modified $\mathrm{SiO}_{2}$ surface (a) and BocAPS-modified $\mathrm{SiO}_{2}$ surface with removed Boc groups (b).

\subsection{Biosensor Fabrication Based on BocAPS SAM}

BocAPS surfaces could be used in biochemical experiments at the stage of biosensor production during biomolecule immobilization. Enzymes are often used as active components of a biosensor [24], thus they were chosen for further modifications.

An assessment of the suitability of the resulting amino surfaces for the immobilization of the enzyme glucose oxidase was carried out. Immobilization of the enzyme was also performed on slides where the Boc group had not been removed. In the case of electrochemical deprotection, in order to assess the selectivity of deprotection at the cathode, anode slides, where the protecting Boc group must remain, were also used in the studies with glucose oxidase. As a control, bare slides (without binding linkers) were used under the conditions of enzyme immobilization; thus, the contribution of possible physical sorption of the enzyme was evaluated. The enzyme activity on the samples in which the Boc group had been removed by trifluoroacetic acid turned out to be significantly greater than the enzyme activity on the samples in which the Boc group had not been removed; furthermore, it was slightly lower than the enzyme activity on the slides in which the amino layer was created using APTES (Figure 5a). This was probably due to the lower planting density of the amino groups when using BocAPS. With the electrochemical removal of the protective groups from the slides, a significantly greater enzyme activity was observed on the cathode samples (with the protective group removed) with respect to the anode samples (with the protective group intact) (Figure 5b). It is worth noting that the activity of the anode slides was comparable to the activity of the control slides, which indicates the preservation of protective groups outside the cathode area during electrochemical deprotection. 

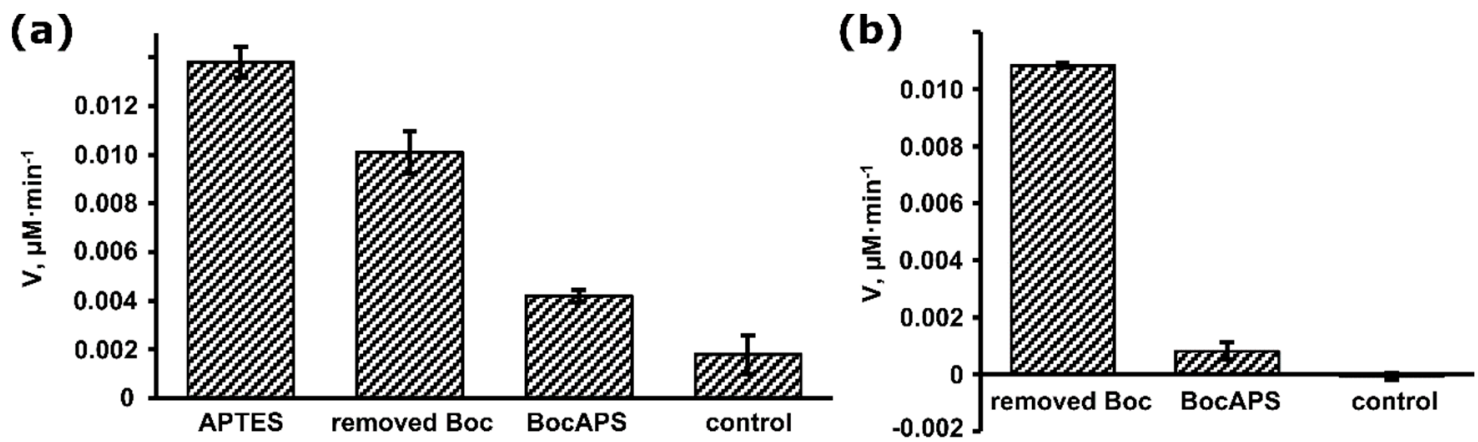

Figure 5. The activity of glucose oxidase immobilized on silicon slides using BocAPS. Chemical deprotection (a), electrochemical deprotection (b).

The fact that a silicon slide with a surface silicon dioxide layer was successfully used as a cathode for electrochemical deprotection indicates the suitability of such an approach for the removal of the Boc group from similar structures, such as ISFETs. This opens the possibility of the selective removal of the Boc group from the sensitive surfaces of an array of ISFETs for further surface modifications.

To demonstrate a practical application, BocAPS was used to create a trinitrotoluene-sensitive sensor based on an ISFET. Unlike surfaces with terminal amino groups, the modified BocAPS surface is stable over time (see Supplementary data Figure S7), and the additional technological stages required for biosensor fabrication can be carried out between BocAPS immobilization and the removal of the protection. After BocAPS was immobilized on the surface of the ISFET, a well-type epoxy structure was made on the top of the crystal (Figure 6a), which included such technological steps as applying a vaseline sacrificial layer, pouring on epoxy resin, and washing the vaseline sacrificial layer (using heating to $95^{\circ} \mathrm{C}$ ). Then, the Boc-group was removed electrochemically from the surface of the transistor, with the surface of the transistor acting as the cathode, and the platinum reference electrode as the anode. Next, the enzyme nitroreductase was immobilized using glutaraldehyde as a linker on the sensitive surface of the ISFET with the terminal amino groups. When the substrate (trinitrotoluene) was added to the well (at a total concentration of TNT $1 \times 10^{-6} \mathrm{M}$ ), the surface potential increased compared to that in the control experiment (Figure 6b). The response of the ISFET to the enzymatic reaction showed the suitability of the obtained SAM as a linker for binding enzymes when creating sensors.
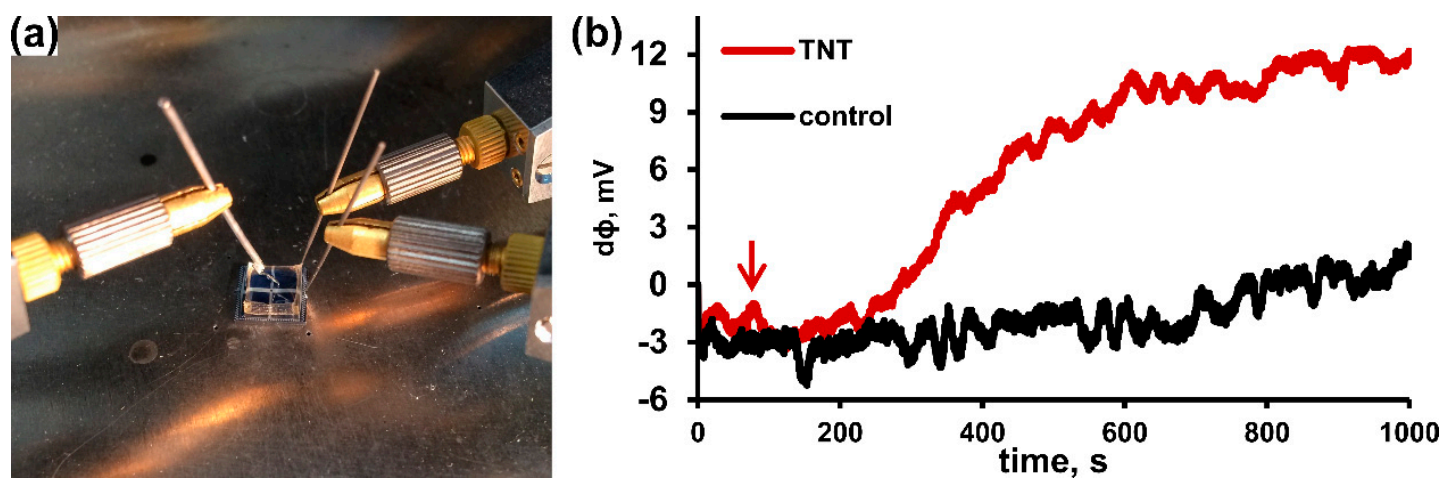

Figure 6. The ion-selective field effect transistor (ISFET) with a well-like structure during the experiments (a). Real-time signal of the ISFET modified with nitroreductase after the addition of trinitrotoluene (indicated by the red arrow) (b).

Further research will aim at creating multicomponent sensors on a single chip, which will be obtained by the sequential removal of protective groups and point modifications with various enzymes. 


\section{Conclusions}

A new surface modifier based on aminopropylsilatrane with a protected amino group, N-tert-butoxycarbonylaminopropylsilatran (BocAPS), was obtained. Its synthesis is simple and can be carried out in any chemical laboratory. BocAPS has greater storage stability compared to APS and APTES, the two most common surface modifiers with a terminal amino group. The protecting group on the BocAPS-modified surface can be removed using chemical and electrochemical methods. The presence of a protective group allows the separation of the two processes of surface modification and creation of the surface amino layer and, thus, the introduction of additional technological steps; this was demonstrated in our example in which a TNT-sensitive biosensor was created. Selective removal of the protective groups on the BocAPS-modified surface can be used for further selective surface modifications with various reagents. This expands the use of BocAPS in technical design.

Supplementary Materials: The following are available online at http://www.mdpi.com/2079-6412/9/11/726/s1, Figure S1: $1 \mathrm{H}$ NMR spectra of BocAPS, $\mathrm{CDCl}_{3}$; Figure S2: $13 \mathrm{C}$ NMR spectra of BocAPS, $\mathrm{CDCl}_{3}$; Figure S3: $1 \mathrm{H}$ NMR spectra of BocAPS (a), glutaraldehyde (c), mixture of BocAPS and glutaraldehyde after $30 \mathrm{~min}$ (b), $\mathrm{D}_{2} \mathrm{O}$; Figure S4: 1H NMR spectra of BocAPS obtained recently (green, there are residues of DMF) and after two years of storage at room conditions (blue), $\mathrm{CDCl}_{3}$; Figure S5: Wettability of parts of the anode and cathode after electrochemical removal of Bocgroups; Figure S6: Survey XPS spectra of the BocAPS-modified $\mathrm{SiO}_{2}$ surface (a) and BocAPS-modified $\mathrm{SiO}_{2}$ surface with removed Boc-groups (b); Figure S7: The activity of glucose oxidase immobilized on silicon slides, which were modified by APTES or BocAPS and had different holding times (at room conditions) between the formation of SAM and the immobilization of the enzyme; Table S1. Selected crystallographic data and details of refinement for N-tert-butoxycarbonylaminopropyl silatrane.

Author Contributions: Conceptualization, K.P. and A.K.; validation, K.P., and V.G.; formal analysis, M.A.; investigation, K.P., S.B., and V.G.; resources, A.K.; writing-original draft preparation, K.P.; writing-review and editing, A.K., V.G., and M.A.; supervision, A.K.; project administration, A.K.; funding acquisition, A.K.

Funding: This research was funded by the Russian Ministry of Education and Science, grant number 0N59-2019-0019.

Acknowledgments: We thank the Center of Collective Use "Functional Control and Diagnostics of Micro- and Nanosystem Engineering based on R\&D Technological Center" (Moscow, Zelenograd) for allowing access to their equipment.

Conflicts of Interest: The authors declare no conflict of interest.

\section{References}

1. Zhao, X.; Kopelman, R. Mechanism of organosilane self-assembled monolayer formation on silica studied by second-harmonic generation. J. Phys. Chem. 1996, 100, 11014-11018. [CrossRef]

2. Aswal, D.K.; Lenfant, S.; Guerin, D.; Yakhmi, J.V.; Vuillaume, D. Self assembled monolayers on silicon for molecular electronics. Anal. Chim. Acta. 2006, 568, 84-108. [CrossRef] [PubMed]

3. Vashist, S.K.; Lam, E.; Hrapovic, S.; Male, K.B.; Luong, J.H.T. Immobilization of antibodies and enzymes on 3-aminopropyltriethoxysilane-functionalized bioanalytical platforms for biosensors and diagnostics. Chem. Rev. 2014, 114, 11083-11130. [CrossRef] [PubMed]

4. Howarter, J.A.; Youngblood, J.P. Optimization of silica silanization by 3-aminopropyltriethoxysilane. Langmuir 2006, 22, 11142-11147. [CrossRef] [PubMed]

5. Huang, K.-W.; Hsieh, C.-W.; Kan, H.-C.; Hsieh, M.-L.; Hsieh, S.; Chau, L.-K.; Cheng, T.-E.; Lin, W.-T. Improved performance of aminopropylsilatrane over aminopropyltriethoxysilane as a linker for nanoparticle-based plasmon resonance sensors. Sens. Actuators, B. 2012, 163, 207-215. [CrossRef]

6. Lyubchenko, Y.L.; Shlyakhtenko, L.S. AFM for analysis of structure and dynamics of DNA and protein-DNA complexes. Methods 2009, 47, 206-213. [CrossRef]

7. Shlyakhtenko, L.S.; Gall, A.A.; Filonov, A.; Cerovac, Z.; Lushnikov, A.; Lyubchenko, Y.L. Silatrane-based surface chemistry for immobilization of DNA, protein-DNA complexes and other biological materials. Ultramicroscopy 2003, 97, 279-287. [CrossRef]

8. Greene, T.W.; Wuts, P.G.M. Protective Groups in Organic Synthesis, 3rd ed.; John Wiley \& Sons, Inc.: New York, NY, USA, 1999. 
9. Tian, J.; Ma, K.; Saaem, I. Advancing high-throughput gene synthesis technology. Mol. Bio. Syst. 2009, 5, 714-722. [CrossRef]

10. Clausmeyer, J.; Schuhmann, W.; Plumeré, N. Electrochemical patterning as a tool for fabricating biomolecule microarrays. TrAC, Trends Anal. Chem. 2014, 58, 23-30. [CrossRef]

11. Johnson, E.K.; Adams, D.J.; Cameron, P.J. Directed self-assembly of dipeptides to form ultrathin hydrogel membranes. J. Am. Chem. Soc. 2010, 132, 5130-5136. [CrossRef]

12. Egeland, R.D.; Southern, E.M. Electrochemically directed synthesis of oligonucleotides for DNA microarray fabrication. Nucleic Acids Res. 2005, 33, 1-7. [CrossRef] [PubMed]

13. Maurer, K.; McShea, A.; Strathmann, M.; Dill, K. The removal of the t-BOC group by electrochemically generated acid and use of an addressable electrode array for peptide synthesis. J. Comb. Chem. 2005, 7, 637-640. [CrossRef] [PubMed]

14. Puchnin, K.; Andrianova, M.; Kuznetsov, A.; Kovalev, V. Field-effect transition sensor for KI detection based on self-assembled calixtube monolayers. Biosens. Bioelectron. 2017, 98, 140-146. [CrossRef] [PubMed]

15. Sheldrick, G.M. A short history of SHELX. Acta Crystallogr. Sect. A. 2008, 64, 112-122. [CrossRef] [PubMed]

16. Dolomanov, O.V.; Bourhis, L.J.; Gildea, R.J.; Howard, J.A.K.; Puschmann, H. OLEX2: A complete structure solution, refinement and analysis program. J. Appl. Cryst. 2009, 42, 339-341. [CrossRef]

17. Gubanova, O.; Andrianova, M.; Saveliev, M.; Komarova, N.; Kuznetsov, E.; Kuznetsov, A. Fabrication and package of ISFET biosensor for micro volume analysis with the use of direct ink writing approach. Mater. Sci. Semicond. Process. 2017, 60,71-78. [CrossRef]

18. Andrianova, M.S.; Gubanova, O.V.; Komarova, N.V.; Kuznetsov, E.V.; Kuznetsov, A.E. Development of a biosensor based on phosphotriesterase and n-channel ISFET for detection of pesticides. Sens. Actuators, $B$. 2015, 221, 1017-1026. [CrossRef]

19. Hencsei, P.; Kovács, I.; Fülöp, V. The crystal structure of 1-( $\gamma$-mercaptopropyl) silatrane. J. Organomet. Chem. 1989, 377, 19-23. [CrossRef]

20. Komarova, N.V.; Andrianova, M.S.; Saveliev, M.I.; Kuznetsov, A.E. Optimization of silicon dioxide surface functionalization protocol for designing the receptor layer of a biosensor for detecting explosives. Mosc. Univ. Chem. Bulletin. 2016, 71, 25-31. [CrossRef]

21. Examples of Boc deprotection. Available online: http://commonorganicchemistry.com/Rxn_Pages/Boc_ Protection/Boc_Protection_TFA.htm (accessed on 10 September 2019).

22. Chow, B.Y.; Emig, C.J.; Jacobson, J.M. Photoelectrochemical synthesis of DNA microarrays. PNAS. 2009, 106, 15219-15224. [CrossRef]

23. Lund, H.; Hammerich, O. Org. Electrochem., 4th ed.; Marcel Dekker, Inc.: New York, NY, USA, 2001; p. 459.

24. Marques, M.E.; Mansur, A.A.P.; Mansur, H.S. Chemical functionalization of surfaces for building three-dimensional engineered biosensors. Appl. Surf. Sci. 2013, 275, 347-360. [CrossRef] 